DOI: http://dx.doi.org/10.30684/etj.37.4C.4

The First International Conference of Engineering Education (1 ${ }^{\text {st }}$ ICEE 2019), Iraq, Baghdad,

\author{
9-10 January 2019
}

\section{Raudhah Ali}

Temenggong Ibrahim Teachers, Training Institute, Malaysia. raudhah@ymail.com

\section{Abdulhadi M. Alsaady \\ Al-Mustaqbal University \\ College, Iraq. \\ dbdalhadyalsdy@gmail.com}

\section{Najah M.L. Al Maimuri \\ Al Furat Al Awsat, Technical University, Kufa, Iraq najahml@yahoo.com}

\title{
Assessing the Level of Reflective Thinking in Engineering Teachers During the Process of Research Action
}

\begin{abstract}
A hydrogeologic study has been adopted to conceptualize the concepts of groundwater levels lowering in swamped area of Tyass, middle of Iraq. 2D dimensional groundwater model and, mitigation model have been used to mitigate the aquifer against high salinity and chemical pollutants by the mitigation theory of heterogeneous subsurface media which basically depends upon physical and mathematical derivation, evaluation of chemical pollutants and total dissolved salts (TDS) of subsurface water before and after mitigation process. The water table level was lowered up to $2.43 \mathrm{~m}$ at the center of a pumping well of abstraction discharge $\left(400 \mathrm{~m}^{3} /\right.$ day) obtained after 2755 days in steady state. The ions concentrations of iron $(\mathrm{Fe})$, zinc $(\mathrm{Zn})$, mercury (Cu), cadmium (Cd), lead $(\mathrm{Pb})$ and TDS in groundwater of 0.4, 3.25, $1.15,0.004,0.033 \mathrm{mg} / \mathrm{liter}$ and $7000 \mathrm{ppm}$ respectively were reduced to less than the allowable limits according to WHO of 0.3, 3, 1, 0.003, 0.01 $\mathrm{mg} / \mathrm{liter}$, 1200 ppm respectively by adding $0.2 \mathrm{WD}$ of fresh water from Hillah river and using maximum no. of pumping wells of (19 at April) after 240 months. The mitigation period was reduced to 120 months when the addition of solvent volume was doubled. Mitigation process in heterogeneous against high saline levels and chemical pollutants has been proven to be a good tool to rehabilitation of polluted aquifers.
\end{abstract}

Keywords- groundwater modeling, mitigation model, Chemical pollutants, Saline level How to cite this article: R. Ali, A.M. Al-Sa'adi and N.M.L. AL Maimuri "Assesing the Level of Reflective
Thinking in Engineering Teachers During the Processof Action Research," Engineering and Technology Journal, Vol. 37, Part C, No. 4, pp. 407-412, 2019.

\section{Introduction}

Our national education system is facing new challenges resulting from globalization in recent years. As such, in the process of education, the role of teachers as practitioners in teaching and learning in the classroom has changed. Without teachers' self-assessment it is very difficult to see how learning can be enhanced or how the curriculum can be assessed [1]. Therefore, action research is seen as a systematic process of self reflection on current practices [2].

Reflections allow teachers to practice selfassessment. Thus, indirectly teachers can think analytically, critically and creatively while reassessing their teaching. To solve the problems or to change teaching practice, teachers can see, examine and determine alternatives in making decisions. Among the key role, reflections enable teachers to determine their justification in changing their behaviour and practices. Among the importance of reflections, they can assist novice teachers in their teaching and learning. It is hoped that novice teachers can learn the values of reflections. Whether within or outside the country, we could notice a culture has developed where future teachers are encouraged to embrace reflections as a means of self-assessment or self evaluation. Hence, this is highly recommended. This recommendation is consistent with the view that believes reflective thinking gives us opportunities to investigate beliefs and implicit assumptions, teaching practice and the outcomes of the teaching practice critically [3]. In addition, teachers must have the ability to reflect systematically about the activities of their own pedagogy in order to improve their teaching practices. In fact, according to [2], without reflection teachers cannot change their practices either consciously or unconsciously. Next, there is a consensus about reflective practice leading towards professional growth [4] and [5].

The importance of reflective practice is also confirmed by [6] which stated that it is difficult to achieve professional growth without reflective practice in the career of a teacher. It is conceded 
too that reflective practice allows teachers to become self-directed, which carries a responsibility for self development. The other view explained that reflective practice also helps future and practising teachers to make progress through the stages of cognitive development and the development from being a trainee teacher to a trained teacher, enabling them to consider teaching from a more interpretive and critical perspectives. In short, in learning how to teach, reflection allows a teacher to do self-assessment, think analytically, critically and creatively, to analyse the important things in their work process and the outcomes and to look at the alternatives in making decisions. Next, teachers can explore solutions based on the characteristics of spiritual, moral, and aesthetic values to change their behaviour.

\section{Practice and Reflective Writing towards Improving Teachers' Professional Development}

Reflection means focusing attention; namely, it means weighing, calculating and making a choice. Reflection emerges as one of the doctrines which aim at learning in class environment with constructive learning approach which is tried to be put into practice in Malaysian National Education system.

[3] expressed reflective thinking as an active, consistent and careful way of thinking. According to [7], reflective thinking is a logical and information-based decision making process which involves the evaluation of the results in the issues related to education [8] and [9].

Reflective writing demonstrates an overall pattern of thought that moves from a technical reflection to the critical reflection level. Reflective writing is one way to review the theories of teaching and professional development. A new way of thinking will be stimulated and through discussions with colleagues, theories and issues that may cause conflicts could be resolved.

The practice of reflection can enrich and stimulate one's professional practice. It acts as a forum to make decisions that resulted in the actions taken on the teaching contexts. Reflection proposed by [3] became a cornerstone in the study of cognitive processes of teachers in making decisions about teaching and learning.

The development of reflection requires the development of attitudes and abilities such as openness, willingness to accept responsibilities for making decisions and taking actions. Reflection provides an opportunity for teachers to analyse themselves and are aware of their strengths and weaknesses. With this, teachers can make modifications and adaptations as well as improve their teaching and learning process effectively.

Writing journals / reflections can improve the professionalism of teachers because it serves as a vehicle to reflect systematically and to stimulate active thinking. Studies showed that this activity is one of the best strategies to encourage teachers to adopt a reflective investigation and practise self-assessment in dealing with the issues of teaching and learning [10] and [11].

In reflective writing, [12] distinguishes the concept of reflection in action and reflection on action. The former is where a teacher is experiencing a situation, then thinking about what to do next and finally acting straight away, whereas the latter is where a teacher looks back and thinks about the problem/s that exist and analyse the situation before planning follow-up actions. In summary, according to Schon's theory [12] there are two types of reflection, one during and one after an activity or event. Both types of reflections can help teachers grow in their professional fields.

[3] stated that individuals who practise the idea of reflection are always active in thinking about their problems, committed to find solutions, are willing to sacrifice their time to ensure that the problems encountered could be solved and always accept ideas from others in view of any potentials to solve the problems faced. For [13] reflection is the process of neutralizing the negative feelings surrounding all experiences that can produce a new perspective from the experience thus succeeded in changing the behaviour and actions of an individual. It is also a purposeful and careful action [14], making a critical assessment [15] and involves the process of investigating and identifying the experiences that one went through.

In conclusion, the reflective thought and practice are cognitive activities which require the active involvement of individuals as a result of the outburst of an experience that deeply affects them and involves testing the reactions, beliefs and rationale to generate integration of new understanding and past experiences. It is also very necessary to apply to teachers as it is a key and essential element for those who are just starting to get to know the world of teaching [16]. [17] defines reflective thinking, which has an important place in education system, as a questioning method that features caring others' feelings and pays attention to constructivism in learning and as a whole of creative problem solving activities. 
According to [18], action research is a form of collective self-reflective enquiry undertaken by participants in social situations in order to improve the rationality and justice of their own social or educational practices, as well as their understanding of these practices and the situations in which these practices are carried out. [18]. Also claim that the actions undertaken go through a cycle of self-reflection (self-reflective spiral) of a rolling cycle consisting of planning, implementing, evaluating, and planning again, implement, evaluate and reflect. In this context, reflection occurs in the study of the actions carried out starting from the first step to the final step [19] and [12].

Reflective practice and reflective thought are rather difficult to define explicitly. [20] believed that writing plays an excellent role as evidence that allows teachers to translate their thoughts expressively and to adjust accordingly. Hence reflective writing includes both description and analysis and helps individuals to clarify their thoughts, understand important aspects, identify areas where they need more help and work out strategies for solving problems.

It also helps them to personalise and contextualise their own learning experience. A very effective tool to apply the reflective thought and practice is a reflective journal. The reflective journal of an individual can consist of critical experiences or problems encountered and she will consider all possibilities and trying to find various alternatives to address the situation [21].

In conclusion, reflection provides a rich and comprehensive basis about teaching and learning. It not only allows teachers to gain a sense of responsibility, but it gives a wide perspective on the lessons to be emulated or studied by other teachers [22]. In the meantime, reflection has personal values that led to the intrinsic satisfaction when teachers can analyse a situation or experience as good as possible and form a single logical view.

\section{Research Methodology}

The objective of this study is to explore and examine the reflective thought and practice of trainee teachers in conducting action research in schools; the level of their reflective thought and the stage of their reflective practice.

This study uses a qualitative case study methods of various cases, of various places or multi-site case study [23]. Any case study that uses a qualitative approach not only allows researchers to meet with the participants, but also to ensure what is happening and interact with them directly. Figure 1 shows a flowchart for the data collection procedures.

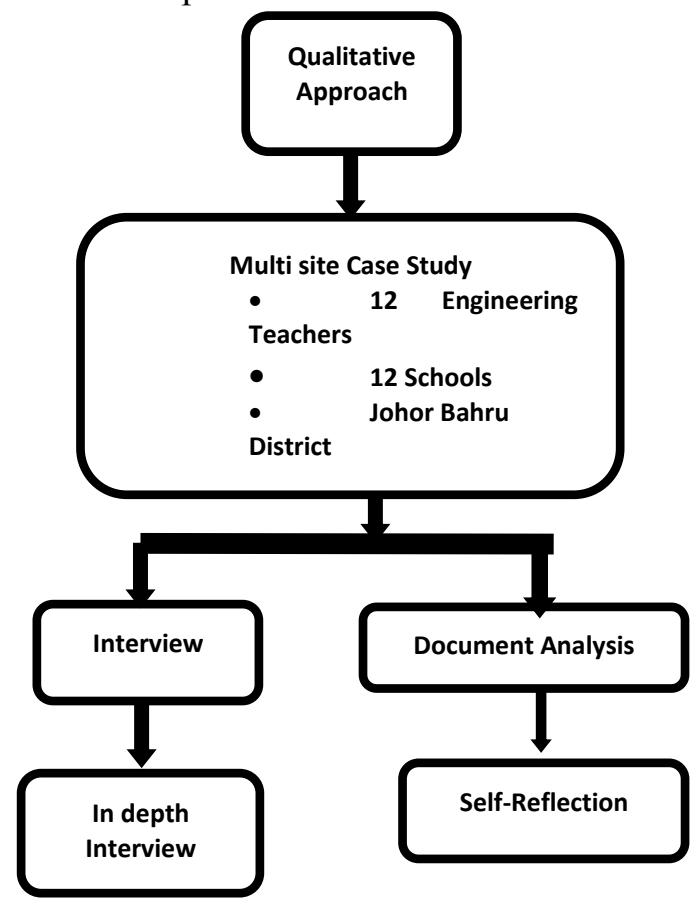

Figure 1: Data Collection Procedure

\section{Participants}

The selection of participants was through purposive sampling method taking into consideration trainee teachers who have done an action research in school and have attended courses of action research in Temenggong Ibrahim Teachers' Training Institute, Johor Bahru during their internship period. The study involved six trainee teachers in the city of Johor Bahru and six engineering teachers in Babylon, Iraq.

\section{Procedures of Analysing Data}

The content analysis method was used to analyse the data. The qualitative data were analysed through the process of reduction or filtering data, display data and derive conclusions as well as do verification [23]. Software NVivo 9th edition has been used for the purpose of facilitating the management of data for generating nodes according to category.

\section{Findings}

The findings have been able to answer the two research questions of the study; the level of the teachers' reflective thought and practice during the implementation process of action research in school and the frequency of the teachers' reflective practice at each stage while implementing the action research in school. 


\section{Trainee Teachers' Thinking Level}

[4] defines three levels of reflection: technical, deliberative, and critical rationality. Technical rationality emphasises achieving the curriculum objectives with no consideration of any problems that the classroom, school, or social contexts may pose [24]. Deliberative rationality emphasises clarifying the values of the context. At the highest level, critical rationality, social conditions, moral, and ethical values are taken into consideration. Critical rationality involves "a constant critique of domination, of institutions, and of repressive forms of authority" [4]. Educational decisions are made on the basis of justice, equality, and freedom. According to [25], reflection is not only a learning activity, but more importantly an ethical tool that utilises social and personal values.

Table 1 shows all of the participants have higher levels of critical thinking as opposed to the technical and practical level. This means teachers are more concerned about issues related to education, teaching methods, the attitude of the teachers and views about the students' abilities and conditions as well as incorporating social issues, ethics and professional conduct as recommended by [4]. It is found that the critical thinking level is the most prominent compared to the level of practical thinking and the technical thinking of the twelve teachers involved. This indicates that Trainee Teacher 5 has the highest level of critical thinking, while Trainee Teacher 1 has the lowest level of critical thinking among all the other teachers involved. Trainee Teacher 3 also has the highest practical and technical level of thinking compared to other trainee teachers.

Table 1: Analysis of Teachers' Reflective Thinking Level

\begin{tabular}{lllll}
\hline \hline $\begin{array}{l}\text { Participant/ } \\
\text { Level }\end{array}$ & Technical & Practical & Critical & Total \\
\hline T1 & 2 & 0 & 2 & 4 \\
T2 & 5 & & 3 & 8 \\
T3 & 8 & 5 & 12 & 25 \\
T4 & 5 & 0 & 6 & 11 \\
T5 & 5 & 2 & 3 & 37 \\
T6 & 2 & 4 & 6 & 12 \\
T7 & 2 & 2 & 11 & 15 \\
T8 & 3 & 2 & 6 & 11 \\
T9 & 1 & 0 & 11 & 12 \\
T10 & 2 & 0 & 9 & 11 \\
T11 & 6 & 2 & 10 & 18 \\
T12 & 2 & 1 & 4 & 7 \\
No. Of & 43 & 18 & 110 & 117 \\
Writings & & & & \\
\hline
\end{tabular}

\section{Frequency of Trainee Teachers' Reflective Practice at Each Stage.}

It was noted that many of the trainee teachers did reflections at the initial stage (32 documents), compared to at the middle stage (18 documents) and at the final stage (10 documents) while conducting their action research respectively (Figure 2).

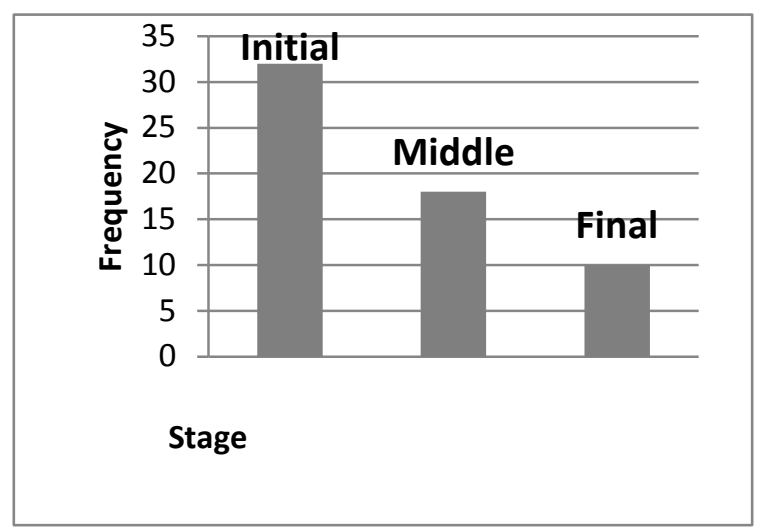

Figure 2: Frequency of reflection stage of trainee teachers

\section{Reflections at the Initial Stage}

Reflections at the initial stage at the starting point of the action research is more focused on looking at issues briefly or just doing analysis of a situation, determine the issues and areas of concern, determine the focus of the investigation or doing analysis of own understanding or with the help of another trainee teacher (Figure 2).

These trainee teachers too while doing reflections during the initial stage focused more on the ways to achieve the goals of teaching and learning. Most of them did reflections at this initial stage by only reviewing and analysing a situation.

\section{Reflections at the Middle Stage}

It was also discovered that these trainee teachers did reflections in the middle stage that is while conducting the action research. This caused them to improve or change their actions or thoughts, especially when encountered with an unexpected situation or a problem (Figure 2).

For instance, Trainee Teacher 3, she used different strategies to cater for her mixed ability students who have different abilities, while Trainee Teacher 2 changed her mind or presumptions against her students who were deemed weak in all respects. By her observation on the students in the computer room, she discovered that all her presumptions about them were wrong. 


\section{Reflections at the Final Stage}

This type of reflection at the final stage of reflection after the action focused more on reassessing the understanding and perceptions, and determining conclusions, and further actions (Figure 2).

Trainee Teacher 3 for example, through her reflections at the final stage, has managed to make conclusions on her action research that has been implemented. She assumed that the remedial module through a fun learning program in English language that she conducted has facilitated teaching and learning. It was evident that the sudents' confidence level in answering test questions in English language improved.

While for Trainee Teacher 5, failure to achieve her first action research objectives involving letter game activity has caused her to modify the instructions on the worksheet to undertake further action in her action research.

\section{Discussion and Conclusions}

The findings in this case study illustrated that trainee teachers demonstrated a more open approach to their experiences. They were more proactive and capable of integrating social issues, ethics and professional conduct [4] and [26]. They were also able to influence or control aspects such as curriculum, environment and organization or institution [27]. Trainee Teacher 1 whose critical, practical and technical reflection was the lowest among the other participants, was more committed in achieving the goal of completing lesson plans and in the preparation of teaching materials rather than concentrating on social issues, moral issues, ethics and professional conduct [4] and [26]. This finding also showed that trainee teachers were not very reflective and reflections made were not structured and merely based on experience without having systematic record such as journal or diary writing. It is important to include activities that develop reflective thinking in the training of preservice teachers. Hence, reflective thinking activities should take parts more in the curriculums of the faculties of [20].

This study also disclosed that trainee teachers made less self reflections and this situation is likely to cause them to always blame their students instead of evaluating their own weaknesses.

One implication of our work is the need for exposure to diversity that moves from sweeping reviews of best practices that lack depth and application to content-specific curriculum [28]. There are teachers who are still vague and unclear about the real purpose of writing a reflective journal. In addition, teachers do not have enough time and have too much workload which make it difficult for teachers to focus on innovation efforts, to have discussions with colleagues and do reflections. In carrying out action research, teachers need support from colleagues, friends who are researchers and school administrators in determining the success of the action research undertaken [29].

Teacher training is among the primary issues a country has to give importance to. The fact that teachers are provided with both field competence and teaching professional skills is an issue that needs to be given importance for raising generations needed today and in the future. For teachers to have that field of competence, it is necessary that studies related to the development of knowledge and attitudes regarding to reflective thinking should be done in teacher training programs; because reflective thinking can be a determining factor in the training of effective teachers.

\section{References}

[1] L. Stenhouse, "Introduction to curriculum research and development," London: Heinemens, 1975.

[2] C. Macintyre, "The art of action research in the classroom," London: David Dulton Publishers, 2000.

[3] J. Dewey, "How we think: A restatement of the relation of reflective thinking to the educative process," New York: D.C. Heath and Company, 1975.

[4] M. Van Manen, "Linking ways of knowing with ways of being practical," Curriculum inquiry, 6, 3, 205-228, 1977.

[5] D. McLaughlin, \& P. Hanifin, "Reflection, Rhetoric or Reality: A Case Study in Preservice Teacher Education," Australian Journal of Teacher Education, 20, 1, 1995.

[6] B.E. Steffy, M.P. Wolfe, S.H. Pasch, \& B.J. Enz, "The model and its application," In B.E. Steffy, M. P. Wolfe, S. H. Pasch, \& B. J. Enz, (Eds.), Life cycle of the career Teacher pp. 1-25. California: Kappa Delta $\mathrm{Pi}$ and Corwin Press, Inc, 2000.

[7] G.L. Taggart, A.P Wilson, "Promoting Reflective Thinking in Teachers," 44 Action Strategies. USA: Corwin Press, Inc, 1998.

[8] M. Burbank, L. Ramirez \& A. Bates, "Critically Reflective Thinking in Urban Teacher Education: A Comparative Case Study of Two Participants," Experiences as Content Area Teachers. The Professional Educator, Vol. 36, No. 2, fall 2012, 2012.

[9] F. Dervent, "The Effect of Reflective Thinking on The Teaching Practices of Preservice Physical 
Education Teachers. Issues in Educational Research, 25, 3, pg. 260-275, 2015.

[10] F.S. Bolin, "Helping student teachers think about teaching," Journal of Teacher Education, 39, 2, 48-54, 1998.

[11] A.E. Richert, "Teaching teachers to reflect: A consideration of programme structure," Journal of Curriculum Studies, 22, 509-527, 1990.

[12] D.A. Schon, "Educating the reflective practitioner: Towards a new design for teaching and learning in the professions," San Francisco: JosseyBass, 1987.

[13] D. Boud, R. Keogh, D. dan Walker, "Reflection: Turning experience into learning," London: Kogan Page, 1985.

[14] J. Loughran, \& D. Corrigan, "Teaching portfolios: A strategy for developing learning and teaching in the pre-service teacher education. Teaching and Teacher Education, 11, 6, 565-577, 1995.

[15] J. Mezirow, "Transformative Dimensions of Adult Learning," San Francisco: JosseBass, 1991.

[16] M. Giovannelli, "Relationship between Reflective Disposition toward Teaching and Effective Teaching," The Journal of Educational Research. 5, 293-309, 2003.

[17] G.J. Henderson, "Reflective Teaching: The Study of Constructivist Practices," New York: Cornell University Press, 1996.

[18] S. Kemmis, \& R. McTaggart, "The action research planner," Ed. ke-3. Victoria: Deakin University, 1988.

[19] S. Grundy \& S. Kemmis, "Educational action research in Australia: the state of the art (overview)," Dlm. Kemmis, S. \& McTaggart, R. (pnyt). The action research reader, hlm. 321-336. Ed. ke-3. Victoria: Deakin University, 1981.

[20] C. Poyraz \& S. Usta, "Investigation of Preservice Teachers's Reflective Thinking Tendencies," In Terms of Various Variances. International Journal on New Trends in Education and Their Impilcations. April 2013. Vol (4), pg 126-135, 2013.

[21] L. Hoover, "Reflective writing as a window on preservice teachers' thought processes," Teaching and Teacher Education. 10, 1, 83-93, 1994.

[22] B.P. Ying, "Pelaksanaan kerja kursus berportfolio dalam kursus diploma perguruan Malaysia," Tesis Doktor. Falsafah. Universiti Kebangsaan Malaysia, Bangi, 2002.

[23] M.B. Miles and A.M. Huberman, "Qualitative data analysis," $2^{\text {nd }}$ Ed. Thousand Oaks, California: Sage Publications, 1994.

[24] K.M. Zeichner, \& D.P. Liston, "Teaching student teachers to reflect," Harvard Educational Review, 57(1), 23-49, 1987.

[25] H. Gelter, "Why is reflective thinking uncommon," Reflective Practice, 4(3), 337-344, 2003.
[26] M. Van Manen, "Writing Qualitatively," or the demands of writing Keynote Address: Third Nordic Interdisciplinary Conference on Qualitative Methods, 2006.

[27] Z. Knowles, D. Gilbourne, B. Cropley, B. \& L. Dugdill, "Reflecting on reflection and journeys," New York: Routledge, 2004.

[28] A. Castro, "Themes in the research on preservice teachers' views of cultural diversity: Implications for researching millennial preservice teachers," Educational Researcher, 39, 3, 198-210, 2010.

[29] M. Md. Jaafar, "Pelaksanaan kajian tindakan oleh guru di sekolah," Tesis Ijazah Sarjana, Fakulti Pendidikan, Universiti Kebangsaan Malaysia, 2006. 